\title{
The intensive management of Norway spruce: a compromise between financial gain and genetic diversity?
}

\author{
Solveiga Luguza [1], Endijs Bāders [2], Pauls Zeltinš [2], Roberts Čakšs [2], Dainis Edgars Runǵis [2], Āris Jansons [2] \\ [1] Latvia University of Life Sciences and Technology \\ [2] LSFRI Silava
}

\section{INTRODUCTION}

Norway spruce (Picea abies (L.) Karst.) is a high-yielding commercial tree species grown in the Baltic sea region. It not only ensures timber production, but also provides a notable amount of crown branch biomass and a substantial amount of technically accessible stump biomass for energy. Thus, it has a high potential as a source of renewable materials and energy in the bioeconomy. Recent studies in Latvia have shown no long-term negative consequences to forest ecosystems from whole-tree harvesting. Hence, this management method can be considered sustainable for Norway spruce stands in fertile mineral soils. Not only yield, but also risks need to be considered to ensure financial sustainability, mainly the impact of wind-storms, drought, and pests. A combination of silviculture and genetics (tree breeding) can be used to reduce the probability of damage to Norway spruce stands. The aim of our study was to assess the potential of simultaneously ensuring both genetic gain and diversity in Norway spruce plantations.

\section{MATERIALS AND METHODS}

Data characterizing/showing tree growth - current height, diameter at breast height, survival, as well as radial increment (increment cores) - were obtained from a 50-year-old Norway spruce plantation. Data characterizing genetic diversity were collected from a gene reserve stand (48 trees), Norway spruce seed orchard progenies consisting of 20 clones, as well as 12 pure Norway spruce stands. DNA was extracted and analysed with 6 to 14 nuclear SSR markers.

\section{RESULTS}

No significant differences were observed between the seed orchard progenies, the trees from the gene reserve stand and other Norway spruce stands using the assessed parameters - allelic richness, observed heterozygosity, genetic diversity and relatedness. This indicates that the use of a seed orchard containing a relatively low number of clones as a seed source for plant production and forest regeneration would not have a negative impact on genetic diversity. However, notable gains in productivity can be achieved using selected plant material. At the age of 50 years, phenotypically selected clones in the lowdensity $(5 \times 5 \mathrm{~m})$ plantation had a mean yield of $327 \pm 42 \mathrm{~m}^{3} \mathrm{ha}^{-1}$, significantly exceeding the mean yield $\left(277 \pm 56 \mathrm{~m}^{3} \mathrm{ha}^{-1}\right)$ observed in Norway spruce stands of the same age and the same site conditions (forest type), while no significant differences were observed compared to the average stand yield at the age of 80 years $\left(347 \pm 47 \mathrm{~m}^{3} \mathrm{ha}^{-1}\right)$. The target diameter of $31 \mathrm{~cm}$ was reached at the age of $42 \pm 0.9$ years on average, but this varied significantly among clones.

\section{CONCLUSION}

The results demonstrate a notable potential to reduce the rotation period, thereby: a) increasing the availability of raw material for further processing and energy production, and b) reducing financial risks due to lowering the probability that the stand will sustain substantial damage (i.e. wind storm). This gain can be achieved without significantly compromising genetic diversity. Further studies shall address potential changes in genetic diversity at the landscape level over a longer period when using a very limited set of clones. Stands in nature reserves could serve as a basis for comparison in such studies.

\section{KEYWORDS}

Timber production, breeding, risks 